\title{
Peripheral blood and mesenteric lymph node lymphocytes in Crohn's disease
}

\author{
ELIZABETH R RICHENS, CHRISTINE M THORP, P W BLAND, \\ AND K R GOUGH
}

From the Department of Clinical Investigation, Royal United Hospital, Bath, and the Pharmacology Group, University of Bath, Bath

SUMMARY Analysis of peripheral blood lymphocytes from 44 patients with Crohn's disease showed no difference in the proportions of T- and B-cells from those in 38 healthy controls. Analysis revealed no disturbances in relation to duration or to activity of disease or to drug treatment. Lymphocytes from 18 patients with rheumatoid arthritis also showed normal proportions of T- and B-cells. Lymphocytes taken from gut lymph nodes were studied in five patients with Crohn's disease. On comparison with peripheral blood lymphocytes, significantly decreased proportions of T-cells and significantly increased proportions of B-cells were found in lymph nodes draining areas of diseased bowel. No differences were seen in the proportions of T- and B-cells from lymph nodes taken from apparently healthy bowel of the Crohn's patients and of four control subjects without inflammatory bowel disease, though these were different from those in the peripheral blood in both the Crohn's patients and control subjects.

Crohn's disease is a chronic granulomatous inflammatory condition predominantly affecting the gastrointestinal tract. The mechanism of damage is not known, but the immune response is thought to be important because it has been demonstrated that azathioprine is able to maintain, alone or in combination, a remission induced by corticosteroids. ${ }^{1-8}$ Autoimmune reactions are also suggested by the finding that lymphocytes from Crohn's patients exhibit migration inhibition ${ }^{45}$ and give positive cytotoxic reactions ${ }^{67}$ in the presence of colon extracts and cells respectively.

There have also been many conflicting reports on the level of non-specific immune responsiveness in Crohn's disease ${ }^{8}$ and the relative numbers of $\mathrm{T}$ - and B-cells in the peripheral blood are still disputed. ${ }^{9-12}$

There are numerous prominent large lymph nodes in the area of the diseased bowel in Crohn's disease; thus, in an investigation of immune status in the condition, it may be more relevant to study lymphocytes from these sites. Hence we report here the results of a study of the surface characteristics of lymphocytes from this source against a background of data obtained from peripheral blood lymphocytes of patients with Crohn's disease.

Received for publication 23 October 1979

\section{Methods}

\section{PATIENTS}

For the measurement of B- and T-lymphocytes in the peripheral blood, 44 patients with Crohn's disease were studied. Their ages ranged from 16 to 72 years (mean 47 years) and length of history from less than one to 24 years (mean 7.8 years). Activity of disease was judged by clinical criteria including fever, weight loss, abdominal pain, and diarrhoea. Thirty-eight healthy control subjects and 18 patients with rheumatoid arthritis were also studied. Both groups were proportionately age- and sex-matched with the patients with Crohn's disease.

To measure the B- and T-lymphocytes of the gut wall five patients with Crohn's disease were studied. Their clinical details are shown in Table 1.

The four control patients included one with peptic ulcer, two with appendicitis, and one with local cancer of the small bowel.

\section{LYMPHOCYTE SOURCES}

In most of this work, peripheral blood lymphocytes were used. They were separated from whole blood as described below.

When lymph node lymphocytes were used, they were obtained from the lymph nodes in the mesentery of freshly resected bowel. Microscopic granuloma 
Table 1 Details of patients with Crohn's disease from whom lymph node lymphocytes were assessed

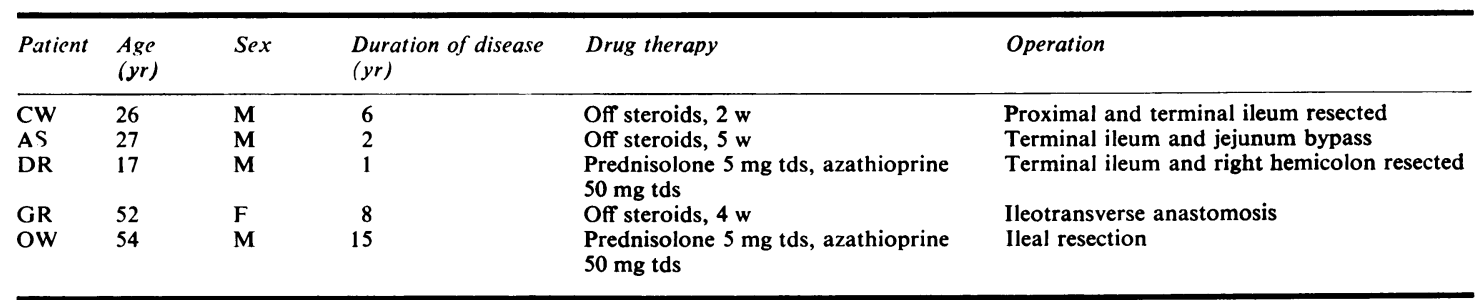

formation was present in resected areas of all Crohn's disease patients. Lymph nodes were taken from frankly diseased areas and from apparently healthy bowel of the Crohn's patients, usually at least $20 \mathrm{~cm}$ from the site of disease.

The lymph nodes were removed at laparotomy and the tissue fat surrounding the node dissected away. The nodes were cut finely with scissors, macerated and then gently pressed through a $33 \mu$ diameter sterile stainless steel mesh and collected in Hank's solution. The viability of isolated lymphocytes was $>90 \%$ as judged by trypan blue exclusion.

They were additionally prepared as described below.

\section{LYMPHOCYTE PURIFICATION}

$7.5 \mathrm{ml}$ of blood was diluted in twice its volume of phosphate buffered saline (PBS) containing $20 \mathrm{U} / \mathrm{ml}$ heparin. This diluted blood was then layered over $5 \mathrm{ml}$ of Ficoll-Triosil of specific gravity 1.077 and centrifuged at $400 \mathrm{~g}$ for 15 minutes at $20^{\circ} \mathrm{C}$. The mononuclear cells at the interface were collected and washed three times in minimal essential medium (MEM).

\section{LYMPHOCYTE SURFACE MARKERS}

Spontaneous rosettes with sheep red blood cells

Blood cells were characterised as T-cells by rosette formation with sheep red blood cells. ${ }^{13} 1-2 \times 10^{6}$ washed, purified mononuclear cells were pelleted at the bottom of a $72 \times 12 \mathrm{~mm}$ plastic tube (Luckhams) and $0.4 \mathrm{ml}$ of a $1 \%$ suspension of sheep erythrocytes (Mercia Diagnostics) in heat inactivated sheep red cell absorbed fetal calf serum (HI-FCS) was added. The cells were incubated at $37^{\circ} \mathrm{C}$ for 15 minutes, pelleted at $100 \mathrm{~g}$ for five minutes and then left at $4^{\circ} \mathrm{C}$ overnight. On the following day most of the HI-FCS was removed and the cells gently resuspended in the remaining drop. A smear was made with a coverslip and stained with Giemsa. The number of lymphocytes binding three or more red cells was enumerated. At least 200 cells were counted.

\section{Surface membrane immunoglobulin}

Blood cells were characterised as B-cells by staining for surface immunoglobulin. ${ }^{14} 1-4 \times 10^{8}$ purified mononuclear cells were washed three times in PBS at $37^{\circ} \mathrm{C}$ to remove passively absorbed immunoglobulin $^{15}$ and then resuspended in one drop PBS.

One drop of a 1.5 dilution of FITC conjugated sheep anti-human immunoglobulin (Wellcome) in PBS was added and the cells incubated at $4^{\circ} \mathrm{C}$ for 20 minutes and then washed three times in PBS. Dried unfixed smears were viewed under incident ultra-violet and phase contrast microscopy to determine the percentage of fluorescing lymphoid cells. At least 200 cells were scanned.

\section{STATISTICAL PROCEDURES}

Significances in differences in the proportions of peripheral blood T- and B-cells between patient groups and between the different categories of patients with Crohn's disease were assessed by Student's $t$ test. The Mann-Whitney U test was used to analyse the lymph node data.

\section{Results}

The proportions of T- and B-cells in the peripheral blood of control subjects and of patients with Crohn's disease and rheumatoid arthritis is shown in Table 2. There was no statistical difference

Table $2 T$ - and B-cell proportions in peripheral blood in Crohn's disease, rheumatoid arthritis, and normal control subjects

\begin{tabular}{|c|c|c|c|c|c|c|}
\hline & \multicolumn{2}{|c|}{ Normal control subjects } & \multicolumn{2}{|c|}{ Crohn's disease } & \multicolumn{2}{|c|}{ Rheumatoid arthritis } \\
\hline & $\begin{array}{l}\text { No. samples } \\
\text { tested }\end{array}$ & $\begin{array}{l}\text { Percentage of cells } \\
\text { mean } \pm S D\end{array}$ & $\begin{array}{l}\text { No. samples } \\
\text { tested }\end{array}$ & $\begin{array}{l}\text { Percentage of cells } \\
\text { mean } \pm S D\end{array}$ & $\begin{array}{l}\text { No. samples } \\
\text { tested }\end{array}$ & $\begin{array}{l}\text { Percentage of cells } \\
\text { mean } \pm S D\end{array}$ \\
\hline $\begin{array}{l}\text { T-cells } \\
\text { B-cells }\end{array}$ & $\begin{array}{l}38 \\
38\end{array}$ & $\begin{array}{l}51 \cdot 2 \pm 7 \cdot 4 \\
24 \cdot 6 \pm 8 \cdot 0\end{array}$ & $\begin{array}{l}60 \\
40\end{array}$ & $\begin{array}{l}50 \cdot 9 \pm 9 \cdot 3 \\
25 \cdot 5 \pm 6 \cdot 6\end{array}$ & $\begin{array}{l}18 \\
17\end{array}$ & $\begin{array}{l}50 \cdot 0 \pm 6 \cdot 2 \\
23 \cdot 7 \pm 7 \cdot 5\end{array}$ \\
\hline
\end{tabular}


Table 3 Clinical correlations with $T$ - and B-cells in Crohn's disease

\begin{tabular}{|c|c|c|c|c|c|}
\hline \multicolumn{2}{|l|}{ Clinical state } & \multicolumn{2}{|c|}{ Percentage of $T$-cells $\pm S D$} & \multicolumn{2}{|c|}{ Percentage of B-cells $\pm S D$} \\
\hline $\begin{array}{cc}\text { Duration of disease }(y r) \\
<2 & (16)^{*} \\
2-5 & (14) \\
5-10 & (9) \\
>10 & (5)\end{array}$ & & $\begin{array}{l}46 \cdot 7 \pm 5 \cdot 9 \\
46 \cdot 7 \pm 6 \cdot 3 \\
50 \cdot 8 \pm 7 \cdot 5 \\
49 \cdot 9 \pm 12 \cdot 8\end{array}$ & $\begin{array}{l}(19) \dagger \\
(18) \\
(17) \\
(6)\end{array}$ & $\begin{array}{l}24 \cdot 7 \pm 8 \cdot 4 \\
24 \cdot 1 \pm 7 \cdot 9 \\
23 \cdot 8 \pm 7 \cdot 4 \\
27 \cdot 0 \pm 5 \cdot 7\end{array}$ & $\begin{array}{r}(12) \\
(8) \\
(17) \\
(3)\end{array}$ \\
\hline $\begin{array}{l}\text { Drug therapy } \\
\text { Steroids } \\
\text { Steroids and azathioprine } \\
\text { Salazopyrin and codein } \\
\text { No therapy }\end{array}$ & $\begin{array}{r}(11) \\
(16) \\
(8) \\
(9)\end{array}$ & $\begin{array}{l}47 \cdot 1 \pm 6 \cdot 9 \\
50 \cdot 9 \pm 7 \cdot 4 \\
51 \cdot 9 \pm 7 \cdot 3 \\
50 \cdot 8 \pm 8 \cdot 4\end{array}$ & $\begin{array}{r}(27) \\
(14) \\
(10) \\
(9)\end{array}$ & $\begin{array}{l}25 \cdot 5 \pm 8 \cdot 0 \\
24 \cdot 0 \pm 6 \cdot 6 \\
23 \cdot 6 \pm 4 \cdot 1 \\
24 \cdot 8 \pm 9 \cdot 9\end{array}$ & $\begin{array}{r}(20) \\
(12) \\
(4) \\
(4)\end{array}$ \\
\hline $\begin{array}{l}\text { Disease activity } \\
\text { Quiescent } \\
\text { Active }\end{array}$ & & $\begin{array}{l}52 \cdot 1 \pm 6 \cdot 3 \\
48 \cdot 2 \pm 7 \cdot 2\end{array}$ & $\begin{array}{l}(40) \\
(20)\end{array}$ & $\begin{array}{l}24 \cdot 0 \pm 6 \cdot 1 \\
24 \cdot 6 \pm 8 \cdot 3\end{array}$ & $\begin{array}{r}(30) \\
(9)\end{array}$ \\
\hline
\end{tabular}

*Number of patients in each group. †Number of samples tested.

between any of these groups. Similarly, no statistical difference could be detected in the proportions of T- and B-cells when patients with Crohn's disease were analysed to see whether such factors as duration of disease, drug therapy, or disease activity exerted a modifying effect (Table 3 ).

Four control subjects and five patients with Crohn's disease were further studied to compare the proportions of $\mathrm{T}$ - and B-cells in peripheral blood and in mesenteric lymph nodes (Figure).

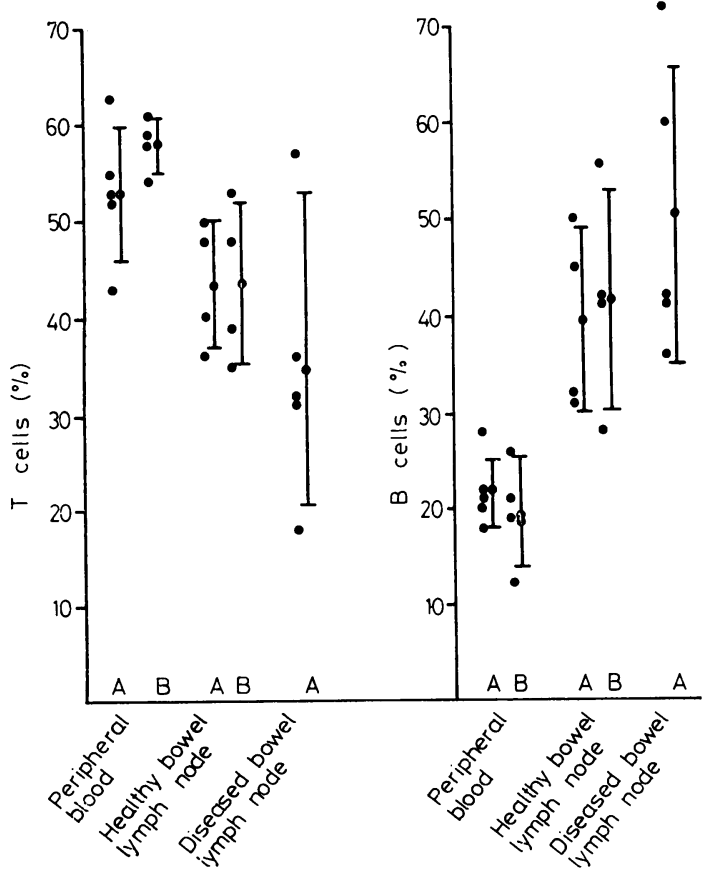

Figure $T$ - and B-cell proportions from peripheral blood, healthy bowel lymph node and diseased bowel lymph node in Crohn's disease (A) and control subjects (B).
In the control subjects, the proportions of peripheral blood $\mathrm{T}$ - and B-cells were in the same ranges as those in the larger groups shown in Table 2 $(59.5 \pm 2.9$ and $19.5 \pm 5.8$ respectively). Enumeration of lymphocytes from the mesenteric lymph nodes showed that the proportions of T-cells were reduced $(43.7 \pm 8 \cdot 2)$, whereas the proportions of B-cells were increased $(41 \cdot 7 \pm 11 \cdot 4)$. These differences are significant ( $P=0 \cdot 014$, in both cases).

In the patients with Crohn's disease the proportions of T- and B-cells in the peripheral blood were again within the normal ranges $(53 \cdot 7 \pm 7 \cdot 1$ and $21 \cdot 8 \pm 3 \cdot 8$ respectively). Decreasing proportions of T-cells were found along the lymphatic drainage route of the gut towards the site of pathology. Hence lymph nodes from apparently healthy areas of the gut contained intermediate levels of T-cells $(43.5 \pm 6 \cdot 6)$, while those from diseased areas were lower $(34 \cdot 8 \pm 9 \cdot 5)$. Both these values are significantly lower than the levels seen in the peripheral blood $(\mathrm{P}=0.048$ and $\mathrm{P}=0.032$ respectively). The proportions of B-cells show an opposite trend, the lowest proportions being found in peripheral blood and higher levels being found in lymph nodes from apparently unaffected (39.5 \pm 9.5$)$ and diseased $(50 \cdot 2 \pm 15 \cdot 2)$ areas of bowel. The lymph node levels of B-cells are, again, significantly different from the levels in peripheral blood $(\mathrm{P}=0.008$ and $\mathrm{P}=0.004$ respectively).

When lymph nodes from diseased areas were compared with those from apparently healthy areas in the same patients, it was seen that those from the diseased areas contained lower proportions of T-cells (34.8 $\pm 9 \cdot 5$ and $43.5 \pm 6 \cdot 6$ respectively) and higher proportions of B-cells $(50 \cdot 2 \pm 15 \cdot 2$ and $39 \cdot 5 \pm 9 \cdot 5$ respectively). However, these differences were not significant $(P=0.095$ and $P=0.143$ respectively).

When the peripheral blood lymphocytes from the patients in this small group were compared with 
those from the control subjects the proportions of T-cells (53.7 $\pm 7 \cdot 1$ and $58.0 \pm 2.9$ respectively) and of B-cells $(21.8 \pm 3.8$ and $19.5 \pm 5.8$ respectively) were not significantly different $(P=0.150$ and $P=0.730$ respectively). Similarly, when lymphocytes from the apparently healthy lymph nodes of patients with Crohn's disease were compared with those from the control subjects the proportions of T-cells (43.5 \pm 6.6 and $43 \cdot 7 \pm 8 \cdot 2)$ and of B-cells (39.5 $\pm 9 \cdot 5$ and $41 \cdot 7 \pm 11 \cdot 4$ ) were not significantly different $(\mathrm{P}=0.278$ and $\mathrm{P}=0.557$ respectively).

It was not possible with the small numbers involved in this study to discern any differences between the proportions of lymphocytes from lymph nodes from either the small or large bowel.

\section{Discussion}

Crohn's disease presents several features which suggest participation of the immune response in its pathogenesis and aetiology. Among these are the question of the integrity of the cell-mediated response and lymphocytic infiltration, often with granulomatous lesions in the affected bowel wall. In this study we report that the proportions of both $\mathrm{T}$ - and B-lymphocytes in the peripheral blood of patients with Crohn's disease are in the same ranges as those from healthy control subjects and from patients with a different category of inflammatory disease, rheumatoid arthritis.

When the proportions of lymphocytes from lymph nodes taken from the bowel nodes of patients with Crohn's disease were measured a reduction was found in the proportions of T-lymphocytes the closer their source to the disease lesion. An opposite trend was observed in the proportions of B-lymphocytes, the highest proportions being found in lymph nodes from the diseased gut area. Examination of lymph nodes draining areas of active Crohn's disease shows an increase in reactive lymphoid follicles and immunoglobulin staining cells. ${ }^{16}$ Hence these results are predictable from histological examination. There are many reports of increases in B-cells and plasma cells throughout the gut wall in Crohn's disease. ${ }^{17-20}$ Such findings are suggestive of a vigorous local B-cell response. An increase was also found in the proportions of B-lymphocytes in the lymph nodes of the healthy bowel compared with those in the peripheral blood of patients with Crohn's disease. Similar differences in the proportions of B-lymphocytes were seen in the control group of patients. These figures are also supported by morphological data. ${ }^{21}$

Other investigations into subpopulations of lymphocytes in Crohn's disease found diffusely in the gut wall have shown an increase in $T$-cell proportions in the deeper layers. ${ }^{17} 2022$ However, when the functional capacity of these lymphocytes has been assessed by their ability to respond to phytohaemagglutinin (PHA), it has been found that both diffusely arranged lymphocytes and lymphocytes from lymph nodes in the diseased areas of bowe ${ }^{23}$ are depressed. Guillou et al. ${ }^{23}$ report a gradient of PHA responsiveness along the route of lymphatic drainage of the diseased bowel. This depression could be due to the effect of a virus ${ }^{24}$ or to previous in vivo stimulation. Thus the state of anergy reported in Crohn's desease ${ }^{2025}$ may be explained by invoking processes of antigenic competion in delayed hypersensitivity reactions analagous to that seen in antibody production. ${ }^{26}$ The reduced ability to mount a delayed hypersensitivity response to various antigen ${ }^{2027}$ may thus be explained by sequestration of committed lymphocytes in the granulomas found in this condition. The protection afforded by granulomas ${ }^{28}$ suggests that these might be the site of immune reaction against a putative delayed hypersensitivity antigen operating in disease induction. However, it must be noted that our findings of reduced T-cell numbers are not supported by Britton et al. ${ }^{29}$ who report increases in both $\mathrm{T}$ - and $\mathrm{K}$-cells in the mesenteric lymph nores of patients with Crohn's disease.

We failed to observe any variation in T- or B-cell proportions with duration or activity of disease or with drug therapy. The corticosteroids are the major therapeutic modality for inflammatory and immunologically mediated diseases, though their efficacy is questioned in Crohn's disease. ${ }^{30}$ Azathioprine is reported to reduce relapse rates in Crohn's disease, ${ }^{3}$ but it is suggested that it may be immunostimulatory rather than immunosuppressive, ${ }^{31}$ possibly because of reduced suppressor cell activity. ${ }^{32}$ Other investigations in patients with inflammatory bowel disease have shown that prednisolone ${ }^{33}$ and azathioprine ${ }^{34}$ cause fluctuations in surface markers in the same pattern as the lymphocyte count.

Because we were unable to demonstrate any variations from normality in the proportions of $\mathrm{T}$ - and B-cells in the peripheral blood of patients with Crohn's disease of varying severity and under varying drug regimes but were able to show variations in the bowel wall lymph nodes cells, it may be that corticosteroids have more demonstrable effect at this site. This could be investigated only by additional studies on bowel lymphocytes. Effective separation techniques for bowel lymphocytes will assist such work. ${ }^{35}$

We gratefully acknowledge the financial support given by the Wessex Regional Health Authority during this research. 


\section{References}

${ }^{1}$ Willoughby JMT, Kumar PJ, Beckett J, Dawson AM. Controlled trial of azathioprine in Crohn's disease. Lancet 1971; 2: 944-7.

${ }^{2}$ Rosenberg JL, Levin B, Wall AJ, Kirsner JB. A controlled trial of azathioprine in Crohn's disease. $A m J$ Dig Dis 1975; 20: 721-5.

${ }^{3}$ O'Donoghue DP, Dawson AM, Powell-Tuck J, Brown RL, Lennard-Jones JE. Double blind withdrawal trial of azathioprine as maintenance treatments from Crohn's disease. Lancet 1978; 2: 955-7.

${ }^{4}$ Bendixen G. Cellular hypersensitivity to components of intestinal mucosa in ulcerative colitis and Crohn's disease. Gut 1969; 10: 631-6.

${ }^{5}$ Richens ER, Williams MJ, Gough KR, Ancill RJ. Leucocyte migration studies in Crohn's disease using Crohn's colon homogenate and mitochondrial and microsomal fractions. Gut 1974a; 15: 19-23.

${ }^{6}$ Shorter RG, Huizenga KA, Spencer RJ, Guy SK. The role of lymphotoxin in the cytotoxicity of lymphocytes for colonic epithelial cells. Dig Dis 1972; 17 (8): 689-6.

${ }^{7}$ Stobo JD, Tomasi TB, Huizenga KA, Spencer RJ, Shorter RG. In vitro studies of inflammatory bowel disease. Surface receptors of the mononuclear cell required to lyse allogeneic colonic epithelial cells. Gastroenterology 1976; 70: 171-6.

${ }^{8}$ British Medical Journal. Editorial. Anergy in Crohn's disease: Fact or fiction? Br Med J 1977; 1: 253-4.

${ }^{9}$ Strickland RG, Korsmeyer S, Soltis RD, Wilson D, Williams RC. Peripheral blood T- and B-cells in chronic inflammatory bowel disease. Gastroenterology 1974; 67: 569-77.

${ }^{10}$ Thayer ER, Charland C, Field CE. The subpopulations of circulating white blood cells in inflammatory bowel disease. Gastroenterology 1976; 71: 379-84.

${ }^{1}$ Sachar DB, Taub RN, Rachamander K, et al. T- and B-lymphocytes and cutaneous anergy in inflammatory bowel disease. Ann NY Acad Sci 1976; 278: 565-73.

${ }^{12}$ Auer IO, Buschmann CL, Zeimer E. Immune status in Crohn's disease. Gut 1978; 19: 618-26.

${ }^{13}$ Jondal M, Holm HG, Wigzell $\mathrm{H}$. Surface markers in T- and B-cells. I. A large population of lymphocytes forming non-immune rosettes with sheep red blood cells. $J$ Exp Med 1972; 136: 207-13.

${ }^{14}$ Froland S, Natvig JB, Berdal P. Surface bound immunoglobulin as a marker of B-lymphocytes in man. Nature New Biol 1971; 234: 251-4.

${ }^{15}$ Lobo PJ, Westerreh FB, Horwitz DA. Identification of two populations of immunoglobulin bearing lymphocytes forming non-immune rosettes with sheep red blood cells. J Exp Med 1975; 136: 207-13.

${ }^{16}$ Skinner JM, Whitehead R. A morphological assessment of immunoreactivity in colonic Crohn's disease and ulcerative colitis by a study of the lymph nodes. J Clin Path 1974; 27: 202-6.

${ }^{17}$ Strickland RG, Husby G, Black WC, Williams R. Peripheral blood and intestinal lymphocyte subpopulations in Crohn's disease. Gut 1975; 16: 847-53.

${ }^{18}$ Ferguson R, Alland RN, Cooke WT. A study of the cellular infiltrate of the proximal jejunal mucosa in ulcerative colitis and Crohn's disease. Gut 1975; 16: 205-8.

${ }^{19}$ Baklien K, Brandtzaeg P. Comparative mapping of the local distribution of immunoglobulin containing cells in ulcerative colitis and Crohn's disease of the colon. Clin Exp Immunol 1975; 22: 197-209.

${ }^{20}$ Meuwissen SGM, Feltkramp-Vroom TM, De la Riviere AB, Von dem Bouren AEG, Kr Tyget GN. Analysis of the lympho-plasmacytic infiltrate in Crohn's disease with special reference to identification of lymphocyte subpopulations. Clin Exp Immunol 1976; 17: 770-80.

${ }^{21}$ Cottier H, Turk JL, Sobin L. A proposal for a standardized system of reporting human lymph node morphology in relation to immunological function. J Clin Pathol 1973; 26: 317-31.

${ }^{22}$ Breucha G, Reithmuller G. Intestinal lymphocytes in Crohn's disease. Lancet 1976; 1: 976.

${ }^{23}$ Guillou PJ, Brennan JG, Giles GR. Lymphocyte transformation in the mesenteric lymph nodes of patients with Crohn's disease. Gut 1973; 14: $20-4$.

${ }^{21}$ Whelock EF, Toy ST. Participation of lymphocytes in viral infection. Adv Immunol 1973; 16: 124-84.

${ }^{25}$ Richens ER, Williams MJ, Gough KR, Ancill RJ. Mixed lymphocyte reaction as a measure of immunological competence of lymphocytes from patients with Crohn's disease. Gut 1974; 15: 24-8.

${ }^{26}$ Adler FL. Competition of antigens. Prog Allergy 1964; 8: $41-57$

${ }^{27}$ Meyers S, Sachar DB, Taub RN, Janwitz HD. Anergy to dinitrochlorobenzene and depression of T-lymphocytes in Crohn's disease and ulcerative colitis. Gut 1976; 17: 911-5.

${ }^{28}$ Glass RE, Baker WNW. Role of granulomata in recurrent Crohn's disease. Gut 1976; 17: 75-77.

${ }^{29}$ Britton S, Eklund AE, Bird AG. Appearance of killer (K) cells in the mesenteric lymph nodes in Crohn's disease. Gastroenterology 1978; 75: 218-20.

${ }^{30}$ Smith KC, Rhodes J, Heatley RV, et al. Low dose steroids and clinical relapse in Crohn's disease: a controlled trial. Gut 1978; 19: 606-10.

${ }^{31}$ Gyte GML, Willoughby JMT. The effect of azathioprine on cell mediated immunity to Candida albicans in Crohn's disease. Clin Exp Immunol 1977; 30: 242-51.

${ }^{32}$ Hodgson HFJ, Wands RJ, Isselbacher KJ. Decreased suppressor cell activity in inflammatory bowel disease. Clin Exp Immunol 1978; 32: 451-8.

${ }^{33}$ Clarke JR, Gagnon RF, Gouch FM, Heyworth MR, MacLennon ICM, Truelove SC, Waller CA. The effect of prednisolone on leucocyte function in man. Clin Exp Immunol 1977; 28: 226-32.

${ }^{31}$ Campbell AC, Skinner JM, McLennan ICM. Immunosuppression in the treatment of inflammatory bowel disease. II. The effects of azathioprine on lymphoid cell population in a double blind trial in ulcerative colitis. Clin Exp Immunol 1976; 24: 249-58.

${ }^{35} \mathrm{Bland}$ PW, Richens ER, Lloyd J, Britton D. Isolation and purification of large bowel mucosal lymphoid cells: effect of separation techniques or functional characteristics. Gut 1979; 20: 1037-1046. 